\begin{tabular}{|l|l|l||}
\hline \multicolumn{2}{|c|}{ PublisherInfo } \\
\hline \hline PublisherName & $:$ & BioMed Central \\
\hline \hline PublisherLocation & $:$ & London \\
\hline \hline PublisherImprintName & $:$ & BioMed Central \\
\hline \hline
\end{tabular}

\title{
Articles selected by Faculty of 1000: Pseudomonas putida genome; SAGE analysis of cell death; array analysis of apoptosis; screen for phosphopeptide binding domain; using non- natural amino acids.
}

\begin{tabular}{|l|l|l||}
\hline \multicolumn{2}{|c||}{ ArticleInfo } \\
\hline \hline ArticleID & $:$ & 3460 \\
\hline \hline ArticleDOI & $:$ & $10.1186 /$ gb-2003-4-4-315 \\
\hline \hline ArticleCitationID & $:$ & 315 \\
\hline \hline ArticleSequenceNumber & $:$ & 15 \\
\hline \hline ArticleCategory & $:$ & Paper report \\
\hline \hline ArticleFirstPage & $:$ & 1 \\
\hline \hline ArticleLastPage & $:$ & 3 \\
\hline \hline & $:$ & RegistrationDate : 2003-3-6 \\
ArticleHistory & $:$ OnlineDate $\quad 2003-3-6$ \\
\hline
\end{tabular}




\begin{tabular}{|l||l|l|}
\hline ArticleCopyright & $:$ & BioMed Central Ltd2003 \\
\hline \hline ArticleGrants & $:$ & \\
\hline \hline ArticleContext & $:$ & 130594444 \\
\hline
\end{tabular}

The Author(s)

\section{Summary}

A selection of evaluations from Faculty of $\mathbf{1 0 0 0}$ covering the Pseudomonas putida genome, SAGE and microarray analysis of cell death, a screen for phosphopeptide binding domains and an engineered bacterium that uses a non-natural amino acid.

\section{Pseudomonas putida genome}

Complete genome sequence and comparative analysis of the metabolically versatile Pseudomonas putida KT2440. Nelson KE, Weinel C, Paulsen IT, Dodson RJ, Hilbert H, Martins dos Santos VA, Fouts DE, Gill SR, Pop M, Holmes M, et al. Environ Microbiol 2002, 4:799-808

For the Faculty of 1000 evaluation of this article please see: http://genomebiology.com/reports/F1000/ gb-2003-4-4-315.asp\#Nelson

\section{SAGE analysis of cell death}

A SAGE approach to discovery of genes involved in autophagic cell death. Gorski SM, Chittaranjan S, Pleasance ED, Freeman JD, Anderson CL, Varhol RJ, Coughlin SM, Zuyderduyn SD, Jones SJ, Marra MA. Curr Biol 2003, 13:358-363.

For the Faculty of 1000 evaluation of this article please see: http://genomebiology.com/reports/F1000/ gb-2003-4-4-315.asp\#Gorski

\section{Array analysis of apoptosis}


Genome-wide analyses of steroid- and radiation-triggered programmed cell death in Drosophila . Lee CY, Clough EA, Yellon P, Teslovich TM, Stephan DA, Baehrecke EH. Curr Biol 2003, 13:350-357.

For the Faculty of 1000 evaluation of this article please see: http://genomebiology.com/reports/F1000/ gb-2003-4-4-315.asp\#Lee

\section{Screen for phosphopeptide binding domain}

Proteomic screen finds pSer/pThr-binding domain localizing PIk1 to mitotic substrates. Elia AE, Cantley LC, Yaffe MB. Science 2003, 299:1228-1231.

For the Faculty of 1000 evaluation of this article please see: http://genomebiology.com/reports/F1000/ gb-2003-4-4-315.asp\#Elia

\section{Using non-natural amino acids}

Generation of a bacterium with a 21 amino acid genetic code. Mehl RA, Anderson JC, Santoro SW, Wang L, Martin AB, King DS, Horn DM, Schultz PG. J Am Chem Soc 2003 125:935-939.

For the Faculty of 1000 evaluation of this article please see: http://genomebiology.com/reports/F1000/ gb-2003-4-4-315.asp\#Mehl

This PDF file was created after publication. 